\title{
Streptomyces sundarbansensis sp. nov., an actinomycete that produces 2-allyloxyphenol
}

\author{
Correspondence \\ Joydeep Mukherjee \\ joydeep_envstu@school.jdvu.ac.in \\ mukherjeejoydeep@hotmail.com
}

Streptomycetes remain a rich source of novel bioactive compounds and, on the premise that poorly researched habitats can offer better prospects for discovering new natural products, actinomycetes from such habitats are currently the focus of considerable scientific interest. Poorly explored ecosystems such as estuarine mangroves have the potential to become a new resource for biological and chemical diversity, should salinity be a determinant of bacterial diversity (Hong et al., 2009). Our group (Saha et al., 2006) has described the purification of a bioactive compound (relative molecular weight $300.2 \mathrm{Da}$, predicted molecular formula $\mathrm{C}_{20} \mathrm{H}_{28} \mathrm{O}_{2}$ ) from strain $\mathrm{MS} 1 / 7^{\mathrm{T}}$ isolated from the Sundarbans mangrove forest (the world's largest), India. To the authors' knowledge, the natural product 2-allyloxyphenol was obtained from this strain for the first time in any living organism (Arumugam et al., 2010). A study, based on a combination of genotypic

†These authors contributed equally to this work.

Abbreviations: ISP, International Streptomyces Project; ML, maximumlikelihood; MP, maximum-parsimony; NJ, neighbour-joining.

The GenBank/EMBL/DDBJ accession number for the 16S rRNA gene sequence of strain $\mathrm{MS} 1 / 7^{\top}$ is $\mathrm{AY} 550275$. and phenotypic methods, is reported here to determine the taxonomic position of strain MS1/7 .

Sediments from the Lothian Island of the Sundarbans mangrove forest $\left(20^{\circ} 50^{\prime} \mathrm{N} 88^{\circ} 19^{\prime} \mathrm{E}\right)$ were collected in February 2001. Isolation was carried out by the standard dilution-plating technique on medium containing (per litre): $10.0 \mathrm{~g}$ starch, $3.0 \mathrm{~g}$ casein, $1.0 \mathrm{~g}$ peptone, $10.0 \mathrm{~g}$ malt extract, $0.5 \mathrm{~g} \mathrm{~K}_{2} \mathrm{HPO}_{4}, 1.0 \mathrm{~g}$ yeast extract, $15.0 \mathrm{~g}$ agar, $500 \mathrm{ml}$ natural seawater and $500 \mathrm{ml}$ distilled water ( $\mathrm{pH} \mathrm{7.3).} \mathrm{Strain}$ $\mathrm{MS} 1 / 7^{\mathrm{T}}$ was maintained in the same medium and subcultured every month. Biomass for molecular systematic and most of the chemotaxonomic studies was obtained after incubation in shake flasks at $30{ }^{\circ} \mathrm{C}$ for $96 \mathrm{~h}$ in medium containing (per litre): $2.0 \mathrm{~g}$ starch, $2.0 \mathrm{~g}$ glucose, $2.0 \mathrm{~g}$ soybean meal, 0.5 g yeast extract, $0.25 \mathrm{~g} \mathrm{NaCl}, 0.32 \mathrm{~g} \mathrm{CaCO}_{3}$, $0.005 \mathrm{~g} \mathrm{CuSO}_{4}, 0.005 \mathrm{~g} \mathrm{MnCl}_{2}, 0.005 \mathrm{~g} \mathrm{ZnSO}_{4}, 500 \mathrm{ml}$ natural seawater and $500 \mathrm{ml}$ distilled water $(\mathrm{pH} 7.3)$.

Spore-chain morphology and spore-surface ornamentation of strain MS1 $1 / 7^{\mathrm{T}}$ were studied by examining gold-palladiumcoated dehydrated specimens of 14-day cultures grown on International Streptomyces Project (ISP) 2 agar by scanning 
electron microscopy in an FEI Quanta 200-MK2 electron microscope. The coverslip technique (Zhou et al., 1998) was used to observe hyphae and spore-chain characteristics by light microscopy $(\times 1000)$. Aerial spore mass, substrate mycelial colour, utilization of sugars and the production of diffusible pigments by strain $\mathrm{MS} 1 / 7^{\mathrm{T}}$ were investigated on five ISP agar media following incubation at $28^{\circ} \mathrm{C}$ for 14 days (Shirling \& Gottlieb, 1966).

Physiological characteristics typical of the genus Streptomyces were determined following standard methods. Unless otherwise stated, all cultures (strain $\mathrm{MS} 1 / 7^{\mathrm{T}}$ and reference strains) were grown at $28{ }^{\circ} \mathrm{C}$. Data on ISP characteristics were obtained following Shirling \& Gottlieb (1966) and confirmed from the literature (Küster, 1972; Shirling \& Gottlieb, 1968a, b, 1969, 1972). Carbohydrate utilization was studied on ISP 9 by incorporating $1 \%(\mathrm{w} / \mathrm{v})$ each of arabinose, D-fructose, galactose, glucose, inositol, lactose, maltose, mannitol, mannose, raffinose, rhamnose, sorbitol, sucrose and D-xylose as sole carbon source as well as the amino acids arginine, asparagine, histidine, leucine, methionine, tyrosine and valine as sole carbon/nitrogen sources and incubating the plates for 21 days (Williams et al., 1983). Growth at pH 4-11 (0.5 pH unit intervals), at $20-45{ }^{\circ} \mathrm{C}$ $\left(2.5{ }^{\circ} \mathrm{C}\right.$ intervals), with phenol $(0.1 \%)$ and in the presence of different concentrations of sodium azide was determined following Goodfellow (1971) on ISP 2 with incubation for 14 days. Growth in the presence of 5-20\% (w/v) $\mathrm{NaCl}(1 \%$ intervals) was investigated according to Tresner et al. (1968) by incubating slants of 14-day ISP 2-grown washed saline suspensions for 10 days. Sensitivity/resistance to penicillin, rifampicin and streptomycin were determined following Williams et al. (1983) at antibiotic concentrations recommended by Locci (1989) and incubating the plates for 7 days. Catalase activity was tested on 7-day colonies grown on modified Bennett agar (MBA), while nitrate reduction and $\mathrm{H}_{2} \mathrm{~S}$ production were tested on sloppy nitrate medium following 14 days of incubation (Williams et al., 1983). Degradation tests for adenine, casein, gelatin, starch and Ltyrosine were performed on cultures grown on MBA plates for 21 days according to Williams et al. (1983) and Gordon et al. (1974). Degradation of aesculin was determined by using defined medium (Williams et al., 1983) after 21 days of incubation. Degradation of cellulose strips in yeast extract broth was observed after 6 weeks of incubation (Goodfellow, 1971). Antimicrobial compound production by strain $\mathrm{MS} 1 / 7^{\mathrm{T}}$ was confirmed following the methods described by Arumugam et al. (2010) and Saha et al. (2006). Physiological characteristics that were obtained reproducibly at least three times are presented.

Chromatographic procedures were used to extract and analyse the isomeric forms of diaminopimelic acid (Hasegawa et al., 1983). Isoprenoid quinones and phospholipids were examined by two-dimensional TLC following Minnikin et al. (1984), while whole-cell sugars were identified according to Staneck \& Roberts (1974). Fatty acids were extracted, methylated and estimated by GC with the standard Sherlock MIDI (Microbial Identification) system (Kämpfer \&
Kroppenstedt, 1996). The DNA G + C content of strain MS1/7 ${ }^{\mathrm{T}}$ was ascertained by using the thermal denaturation method of Marmur \& Doty (1962). The $T_{\mathrm{m}}$ value was measured by UV spectroscopy (UV/visible spectrophotometer; Amersham Pharmacia Biotech).

Isolation of chromosomal DNA and PCR amplification of the 16S rRNA gene were carried out according to Chun \& Goodfellow (1995). Sequencing of the PCR product was performed as described by Gu et al. (2006). Pairwise levels of similarity of the nearly complete $16 \mathrm{~S}$ rRNA gene sequence of strain MS $1 / 7^{\mathrm{T}}$ were determined on the EzTaxon server by using identity analysis (Chun et al., 2007). Reference strains for phylogenetic and phenotypic analyses were chosen on the basis of the top hits from this analysis (http://www.eztaxon. org). The nearly complete $16 \mathrm{~S}$ rRNA gene sequence of strain $\mathrm{MS} 1 / 7^{\mathrm{T}}$ was aligned with sequences of the type strains of related species of the genus Streptomyces by using the MUSCLE program, version 1.7 (Edgar, 2004). Phylogenetic analyses were performed according to the neighbour-joining (NJ), maximum-parsimony (MP) and maximum-likelihood (ML) methods by using PAUP* version $4 \mathrm{~b} 10$ (Swofford, 2002). The evolutionary model of substitution was evaluated by using the program jModelTest, version 0.1.1 (Posada, 2008). The $(\mathrm{GTR}+\mathrm{I}+\mathrm{G})$ evolutionary models of substitution were found to be the best fit for the data. Parameters (base frequencies, rate matrix of substitution and types and shapes of gamma distribution) were estimated from the data. To determine the support for each clade, bootstrap analysis was performed with 1000 resamplings. Trees were rooted by using TreeGraph2 (Stöver \& Müller, 2010). Tree topologies were compared by using the online algorithm described by Nye et al. (2006) (http://www.mrc-bsu.cam.ac.uk/personal/ thomas/phylo_comparison/comparison_page.html).

To determine the genomic relatedness of strain MS1/7 ${ }^{\mathrm{T}}$, dot-blot hybridization experiments were carried out with digoxigenin-labelled DNA (Dutta \& Gachhui, 2007) by using the detection kit from Roche Applied Sciences following the manufacturer's instructions. Strains showing pairwise sequence similarity of $99.32 \%$ and above as obtained from the EzTaxon server were selected for comparison. The genomic DNA probe was prepared from strain $\mathrm{MS} 1 / 7^{\mathrm{T}}$, digested with Sall and separated on a $0.7 \%$ agarose gel. Total DNA digests were transferred from gels to nylon membrane by Southern blotting. Hybridization was performed at $75{ }^{\circ} \mathrm{C}$ for $16 \mathrm{~h}$ and the membrane was washed under highstringency conditions (twice with $2 \times \mathrm{SSC} / 0.1 \% \mathrm{SDS}$ at room temperature for $10 \mathrm{~min}$, once with $0.1 \times \mathrm{SSC} / 0.1 \%$ SDS at $75{ }^{\circ} \mathrm{C}$ for $\left.15 \mathrm{~min}\right)$. Quantification of band intensities was performed by using Image J (http://rsb.info.nih.gov/ij/ index.html) by determining relative intensities in rectangles of equal size.

On ISP media 2, 3, 4, 5 and 7 , strain $\mathrm{MS} 1 / 7^{\mathrm{T}}$ formed an extensively branched substrate mycelium and olive green to grey aerial hyphae that carried smooth-surfaced spores in a flexuous (Rectiflexibiles) arrangement (Fig. 1). The strain contained LL-diaminopimelic acid but no diagnostic sugars 


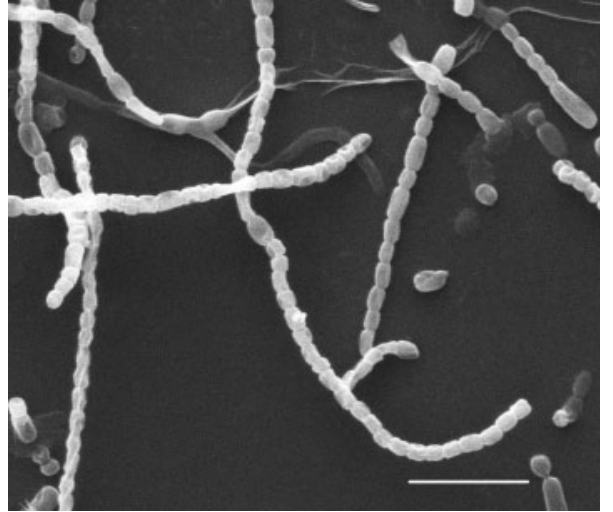

Fig. 1. Scanning electron micrograph showing spore chains and spore surface ornamentation of 14-day-old cells of strain $\mathrm{MS} 1 / 7^{\top}$ grown on yeast-malt extract agar (ISP 2) Bar, $5.0 \mu \mathrm{m}$.

in whole-cell hydrolysates (cell-wall chemotype I sensu Lechevalier \& Lechevalier, 1970). It showed a phospholipid pattern consisting of phosphatidylethanolamine and diphosphatidylglycerol (phospholipid type II sensu Lechevalier et al., 1977). Hexa-, octa- and a minor amount of tetrahydrogenated menaquinones with nine isoprene units [MK-9 $\left(\mathrm{H}_{4}, \mathrm{H}_{6}, \mathrm{H}_{8}\right.$ and $\left.\mathrm{H}_{10}\right)$ ] as isoprene analogues were detected. The predominant fatty acids detected were anteiso$\mathrm{C}_{15: 0}(34.80 \%)$, iso- $\mathrm{C}_{16: 0}(16.45 \%), \mathrm{C}_{16}(10.53 \%)$ and anteiso- $\mathrm{C}_{17: 0}(10.92 \%)$. Thus, strain $\mathrm{MS} 1 / 7^{\mathrm{T}}$ exhibited morphological and chemotaxonomic characteristics typical of members of the genus Streptomyces.

Table 1 shows the results of similarity analysis performed on the 1490 bp $16 \mathrm{~S}$ rRNA gene sequence of strain MS1/7 ${ }^{\mathrm{T}}$. The analysis confirmed that strain MS1/ $7^{\mathrm{T}}$ belonged to the genus Streptomyces, showing greater than $99 \% 16 \mathrm{~S}$ rRNA gene sequence similarity to many members of this genus. The phylogenetic tree based on the NJ algorithm (Fig. 2) shows that strain $\mathrm{MS} 1 / 7^{\mathrm{T}}$ formed a distinct phylogenetic line from the cluster containing the type strains of the Streptomyces species shown in Table 1 . The delineation was supported by significant branch length and a high bootstrap value $(100 \%)$. The phylogenetic position of strain MS $1 / 7^{\mathrm{T}}$ was corroborated by the MP and ML analyses. A similar differentiation of the strain was also found with the MP and ML algorithms and was supported by high bootstrap values ( $95 \%$ for MP and $90 \%$ for ML) as well as considerable branch lengths. In addition, in all three of the trees, strain MS $1 / 7^{\mathrm{T}}$ always grouped with Streptomyces californicus NBRC $3386^{\mathrm{T}}$, Streptomyces puniceus NBRC $12811^{\mathrm{T}}$ and Streptomyces floridae NBRC $15405^{\mathrm{T}}$, members of the viomycin-producing group of the genus Streptomyces (Burkholder et al., 1955), as its closest neighbours, thus confirming the phylogenetic relationship between them. The overall topological scores between the trees were (following Nye et al., 2006): NJ-MP, $83.8 \%$; NJ-ML, 73.9\%; MP-ML, $77.5 \%$. This indicated the similarity in general topology. Results from this part of the taxonomic analysis suggested that strain MS1/7 $7^{\mathrm{T}}$ should be distinguished from the above viomycin-producers as well as other closely related species of the genus Streptomyces by using DNA-DNA hybridization.

Low levels of genomic DNA relatedness (DNA-DNA hybridization values of less than $44 \%$ ) were observed between strain MS1 $/ 7^{\mathrm{T}}$ and the type strains of its phylogenetically closest relatives given in Table 1 . Given the recommended threshold of $80 \%$ DNA-DNA relatedness for differentiating Streptomyces species as proposed by Labeda (1992), strain MS1/7 ${ }^{\mathrm{T}}$ can be distinguished from its closest phylogenetic neighbours.

Table 1. Results of the identity analysis of strain $M S 1 / 7^{\top}$ performed on the EzTaxon server (last accessed 24 August 2010) in relation to the extent of DNA-DNA hybridization with strain $\mathrm{MS} 1 / 7^{\top}$ as determined experimentally

\begin{tabular}{|c|c|c|c|c|c|}
\hline \multirow[t]{2}{*}{ Similar species according to rank } & \multirow[t]{2}{*}{$\begin{array}{c}\text { NCBI accession } \\
\text { no. }\end{array}$} & \multirow[t]{2}{*}{$\begin{array}{l}\text { Pairwise similarity } \\
(\%)\end{array}$} & \multirow{2}{*}{$\begin{array}{c}\text { Dissimilar } \\
\text { nucleotides/total } \\
\text { nucleotides }\end{array}$} & \multicolumn{2}{|c|}{$\begin{array}{c}\text { DNA-DNA hybridization } \\
(\%)^{\star}\end{array}$} \\
\hline & & & & I & II \\
\hline S. californicus NBRC $3386^{\mathrm{T}}$ & AB184755 & 99.451 & $8 / 1458$ & 42.7 & 41.4 \\
\hline S. globisporus NBRC $12867^{\mathrm{T}}$ & AB184203 & 99.451 & $8 / 1457$ & 37.6 & 39.3 \\
\hline S. pluricolorescens NBRC $12808^{\mathrm{T}}$ & AB184162 & 99.450 & $8 / 1454$ & 35.8 & 40.2 \\
\hline S. rubiginosohelvolus NBRC $12912^{\mathrm{T}}$ & $\mathrm{AB} 184240$ & 99.449 & $8 / 1451$ & 40.5 & 37.8 \\
\hline S. badius NRRL B- $2567^{\mathrm{T}}$ & AY999783 & 99.388 & $9 / 1470$ & 36.4 & 42.3 \\
\hline S. anulatus NRRL B- $2000^{\mathrm{T}}$ & DQ026637 & 99.387 & $9 / 1469$ & 33.5 & 36.7 \\
\hline S. albovinaceus NBRC $12739^{\mathrm{T}}$ & AB249958 & 99.383 & $9 / 1459$ & 36.7 & 39.5 \\
\hline S. sindenensis NBRC $3399^{\mathrm{T}}$ & AB184759 & 99.383 & $9 / 1459$ & 37.4 & 41.3 \\
\hline S. parvus NBRC $3388^{\mathrm{T}}$ & AB184756 & 99.383 & $9 / 1459$ & 34.5 & 38.0 \\
\hline S. puniceus NBRC $12811^{\mathrm{T}}$ & $\mathrm{AB} 184163$ & 99.383 & $9 / 1458$ & 41.8 & 43.4 \\
\hline S. floridae NBRC $15405^{\mathrm{T}}$ & AB184656 & 99.383 & $9 / 1458$ & 42.3 & 40.5 \\
\hline S. fimicarius ISP $5322^{\mathrm{T}}$ & AY999784 & 99.320 & $10 / 1470$ & 39.5 & 36.4 \\
\hline
\end{tabular}

${ }^{\star}$ Data for two consecutive tests (I and II) are presented. 




Fig. 2. Unrooted phylogenetic tree based on 16S rRNA gene sequences obtained by the NJ method showing the position of strain $\mathrm{MS} 1 / 7^{\top}$ among its phylogenetic neighbours. Numbers at nodes indicate levels of bootstrap support (\%) based on a NJ analysis of 1000 resampled datasets; only values $>50 \%$ are shown. Asterisks indicate branches that were also recovered using the MP and ML algorithms. GenBank accession numbers are given in parentheses. Bar, 0.1 nt substitutions per site. The sequence of Streptomyces varsoviensis NRRL B- $3589^{\top}$ was used as the outgroup.

Table 2 provides a comparison of the phenotypic characteristics of strain $\mathrm{MS} 1 / 7^{\mathrm{T}}$ with those of the type strains of its 12 closest relatives based on the EzTaxon search and included in the phylogenetic tree (Fig. 2). It was evident that characteristics such as colour of aerial spore mass and colony, and production of diffusible pigments differed significantly between strain $\mathrm{MS} 1 / 7^{\mathrm{T}}$ and the other reference strains. In addition, there were dissimilarities in the utilization of sugars, amino acids, growth with $\mathrm{NaCl}$, degradation of aesculin and resistance/sensitivity pattern to various antibiotics. Strain $\mathrm{MS} 1 / 7^{\mathrm{T}}$ produced 2-allyloxyphenol (Arumugam et al., 2010) and 4a,8a-dimethyl-6-(2-methyl-propenyloxy)-3,4,4a,4b,5,6, 8a,9-octahydro-1H phenanthren-2-one (Saha et al., 2006) as antimicrobial substances, but not viomycin, in contrast to its three closest phylogenetic neighbours (Fig. 2). Strain $M S 1 / 7^{\mathrm{T}}$ could be differentiated from the viomycin-producing species of the genus Streptomyces based on non-utilization of arginine, leucine, methionine and tyrosine as sole nutrients, growth with $\mathrm{NaCl}$, degradation of aesculin and resistance/ sensitivity pattern to various antibiotics.

Based on data from the present study conducted using a polyphasic taxonomic approach, strain $\mathrm{MS} 1 / 7^{\mathrm{T}}$ is thus considered to represent a novel species of the genus Streptomyces, for which the name Streptomyces sundarbansensis sp. nov. is proposed.

\section{Description of Streptomyces sundarbansensis sp. nov.}

Streptomyces sundarbansensis [sun.dar.bans.en'sis. N.L. masc. adj. sundarbansensis pertaining to the Sundarbans (local language, Bangla, meaning the beautiful forest), the world's largest tidal mangrove forest, Republic of India, the geographical origin of the type strain].

Aerobic, Gram-positive-staining, non-motile actinomycete. Spores are borne in flexuous (Rectiflexibiles) chains of 15-30 smooth-surfaced spores, $0.66-0.86 \mu \mathrm{m}$ long and $0.52-$ $0.59 \mu \mathrm{m}$ wide. Grows well on: ISP 2 agar with olive green aerial mycelia and black (reverse side) substrate mycelia; ISP 3 agar with grey to olive green aerial mycelia and brown (reverse side) substrate mycelia; ISP 5 agar with olive green aerial mycelia and brown (reverse side) substrate mycelia; ISP 4 and ISP 7 agar with grey to olive green aerial mycelia and black (reverse side) substrate mycelia. Does not produce diffusible pigments on the above media. No melanoid pigments are produced. Whole-cell hydrolysates contain LLdiaminopimelic acid but no diagnostic sugars. Phosphatidylethanolamine and diphosphatidylglycerol are present as diagnostic phospholipids. The predominant cellular fatty acids are $\mathrm{C}_{15: 0}$, iso- $\mathrm{C}_{16: 0}, \mathrm{C}_{16}$ and anteiso- $\mathrm{C}_{17: 0}$. Utilizes D-fructose, galactose, glucose, lactose, maltose, mannitol, mannose, sorbitol, sucrose and D-xylose as sole carbon source, but not arabinose, inositol, raffinose or rhamnose. Utilizes asparagine, histidine and valine as sole carbon/ nitrogen sources but not arginine, leucine methionine or tyrosine. Positive for catalase activity, but negative for $\mathrm{H}_{2} \mathrm{~S}$ production and nitrate reduction. Degrades adenine, casein, aesculin, gelatin and starch, but not cellulose or L-tyrosine. Grows in the presence of $15 \%(\mathrm{w} / \mathrm{v}) \mathrm{NaCl}$ (optimally in $3 \%$ $\mathrm{NaCl}$ ), at $\mathrm{pH} 4.5-8.5$ (optimally at 7.5 ) and at $25-35{ }^{\circ} \mathrm{C}$ (optimally at $30{ }^{\circ} \mathrm{C}$ ), but not with $0.1 \%$ phenol or different concentrations of sodium azide. Sensitive to streptomycin and rifampicin, but resistant to penicillin. Produces 2allyloxyphenol and 4a,8a-dimethyl-6-(2-methyl-propenyloxy)-3,4,4a,4b,5,6,8a,9-octahydro- $1 \mathrm{H}$ phenanthren-2-one as antimicrobial compounds. 
Table 2. Differential phenotypic characteristics between strain $M S 1 / 7^{\top}$ and phylogenetically related species of the genus Streptomyces

Strains: 1 , MS1 $17^{\mathrm{T}}$; 2, S. californicus NRRL B- $1221^{\mathrm{T}}$; 3, S. floridae MTCC $2534^{\mathrm{T}}$; 4, S. puniceus NRRL B-2895 ${ }^{\mathrm{T}}$; 5, S. rubiginoshelvolus NRRL B-5425 ${ }^{\mathrm{T}}$; 6, S. fimicarius NRRL ISP-5322 $;$; 7, S. globisporus NRRL B- $2872^{\mathrm{T}}$; 8, S. sindenensis NRRL B-1866 ${ }^{\mathrm{T}}$; 9, S. albovinaceus NRRL B-2566 ${ }^{\mathrm{T}}$; 10, S. badius NRRL B-2567 $7^{\mathrm{T}}$; 11, S. pluricolorescens NRRL B-2121 ${ }^{\mathrm{T}}$; 12, S. parvus MTCC $322^{\mathrm{T}}$; 13, S. anulatus NRRL B-2000 ${ }^{\mathrm{T}}$. B, brown; BL, black; G, grey; $\mathrm{N}$, none; OG, olive green; P, pink; PY, pale yellow; R, resistant; $\mathrm{s}$, sensitive; $\mathrm{V}$, violet; $\mathrm{W}$, white; $\mathrm{Y}$, yellow.

\begin{tabular}{|c|c|c|c|c|c|c|c|c|c|c|c|c|c|}
\hline Characteristic & 1 & 2 & 3 & 4 & 5 & 6 & 7 & 8 & 9 & 10 & 11 & 12 & 13 \\
\hline $\begin{array}{l}\text { Colour of aerial spore mass on ISP } \\
\text { media }(2,3,4,5,7)\end{array}$ & OG & G & $\mathrm{W}-\mathrm{V}$ & $\mathrm{Y}$ & $\mathrm{Y}$ & $\mathrm{Y}$ & $\mathrm{Y}$ & G & w & $\mathrm{Y}$ & $\mathrm{Y}$ & $\mathrm{Y}$ & $\mathrm{Y}$ \\
\hline $\begin{array}{l}\text { Reverse side colony colour on ISP } \\
\text { media }(2,3,4,5,7)\end{array}$ & $\mathrm{BL}-\mathrm{B}$ & $\mathrm{v}$ & v & V & $\mathrm{Y}$ & $\mathrm{Y}$ & PY & $\mathrm{N}$ & $\mathrm{N}$ & $\mathrm{N}$ & $\mathrm{Y}$ & PY & PY \\
\hline $\begin{array}{l}\text { Production of diffusible pigments in } \\
\text { ISP media }(2,3,4,5,7)\end{array}$ & $\mathrm{N}$ & $\mathrm{P}$ & v & V & $\mathrm{N}$ & $\mathrm{P}$ & $\mathrm{Y}$ & $\mathrm{N}$ & $\mathrm{N}$ & $\mathrm{N}$ & $\mathrm{N}$ & $\mathrm{Y}$ & $\mathrm{Y}$ \\
\hline \multicolumn{14}{|l|}{ Growth on sole carbon source $(1 \%, \mathrm{w} / \mathrm{v})$} \\
\hline Arabinose & - & - & + & - & + & + & - & + & + & + & + & + & + \\
\hline Rhamnose & - & - & - & - & + & + & - & - & + & - & + & + & + \\
\hline Sorbitol & + & - & - & + & - & + & + & + & - & - & + & - & - \\
\hline Sucrose & + & - & + & - & - & - & - & - & - & - & - & - & - \\
\hline \multicolumn{14}{|l|}{ Growth on sole amino acids $(1 \%, \mathrm{w} / \mathrm{v})$} \\
\hline Arginine & - & + & + & + & + & + & + & + & + & + & + & + & + \\
\hline Leucine & - & + & + & + & + & + & + & + & + & + & + & + & + \\
\hline Methionine & - & + & + & + & + & + & + & + & + & + & + & + & + \\
\hline Tyrosine & - & + & + & + & + & + & + & + & + & + & + & + & + \\
\hline \multicolumn{14}{|l|}{ Resistant/sensitive to antibiotics } \\
\hline Penicillin $\left(10 \mathrm{U} \mathrm{ml}^{-1}\right)$ & $\mathrm{R}$ & $\mathrm{R}$ & $\mathrm{R}$ & s & s & $\mathrm{R}$ & $\mathrm{R}$ & $\mathrm{R}$ & $\mathrm{R}$ & $\mathrm{R}$ & s & s & s \\
\hline Rifampicin $\left(50 \mu \mathrm{g} \mathrm{ml}^{-1}\right)$ & s & s & S & S & $\mathrm{R}$ & s & $\mathrm{R}$ & $\mathrm{R}$ & $\mathrm{R}$ & $\mathrm{R}$ & $\mathrm{R}$ & S & s \\
\hline Streptomycin $\left(100 \mu \mathrm{g} \mathrm{ml}^{-1}\right)$ & s & $\mathrm{R}$ & $\mathrm{R}$ & s & s & s & s & s & $\mathrm{R}$ & s & $\mathrm{R}$ & S & $\mathrm{R}$ \\
\hline Degradation of aesculin & + & - & + & - & - & - & + & - & + & - & + & - & - \\
\hline Growth with $\mathrm{NaCl}(15 \%$, w/v $)$ & + & - & - & - & - & - & - & - & - & - & - & - & - \\
\hline $\begin{array}{l}\text { Production of antimicrobial } \\
\text { substances }{ }^{*}\end{array}$ & $\begin{array}{l}\text { 2-AP and } \\
\text { DMOP }\end{array}$ & Vio & Vio & Vio & $X$ & Gris & Lan & Act & $X$ & $\mathrm{X}$ & Lar & $\mathrm{X}$ & $X$ \\
\hline
\end{tabular}

${ }^{*}$ Act, actinomycin D (Praveen et al., 2008); 2-AP, 2-allyloxyphenol (Arumugam et al., 2010); DMOP, 4a,8a-dimethyl-6-(2-methyl-propenyloxy)3,4,4a,4b,5,6,8a,9-octahydro-1H phenanthren-2-one (Saha et al., 2006); Gris, griseorubin (Dornberger et al., 1980); Lan, landomycin (Ostash et al., 2005); Lar, largomycin (Zaheer et al., 1985); Vio, viomycin (Burkholder et al., 1955); X, no antimicrobial substances reported.

The type strain, MS1/7 $7^{\mathrm{T}}\left(=\right.$ MTCC $10621^{\mathrm{T}}=$ DSM $\left.42019^{\mathrm{T}}\right)$, was isolated from sediments of the Sundarbans mangrove forest, India. The $\mathrm{G}+\mathrm{C}$ content of the genomic DNA of the type strain is $71.9 \mathrm{~mol} \%$.

\section{Acknowledgements}

Financial support through CSIR Grant No. 60(0070)/05/EMR-II and the DST PURSE scheme to J.M. and R. G. is gratefully acknowledged. We thank Dr Debasree Dutta and Mrs Saheli Samanta for their help and suggestions. We are indebted to Mr James Swezey of ARS (USDA), USA, for the kind gift of ten reference strains and to Dr Markus Göker of DSMZ, Germany, for his advice on phylogenetic trees.

\section{References}

Arumugam, M., Mitra, A., Jaisankar, P., Dasgupta, S., Sen, T., Gachhui, R., Kumar Mukhopadhyay, U. \& Mukherjee, J. (2010). Isolation of an unusual metabolite 2-allyloxyphenol from a marine actinobacterium, its biological activities and applications. Appl Microbiol Biotechnol 86, 109-117.
Burkholder, P. R., Sun, S. H., Anderson, L. E. \& Ehrlich, J. (1955). The identity of viomycin-producing cultures of Streptomyces. Bull Torrey Bot Club 82, 108-117.

Chun, J. \& Goodfellow, M. (1995). A phylogenetic analysis of the genus Nocardia with 16S rRNA gene sequences. Int J Syst Bacteriol 45, 240-245.

Chun, J., Lee, J. H., Jung, Y., Kim, M., Kim, S., Kim, B. K. \& Lim, Y. W. (2007). EzTaxon: a web-based tool for the identification of prokaryotes based on $16 \mathrm{~S}$ ribosomal RNA gene sequences. Int J Syst Evol Microbiol 57, 2259-2261.

Dornberger, K., Berger, U. \& Knöll, H. (1980). Griseorubins, a new family of antibiotics with antimicrobial and antitumor activity. I. Taxonomy of the producing strain, fermentation, isolation and chemical characterization. J Antibiot (Tokyo) 33, 1-8.

Dutta, D. \& Gachhui, R. (2007). Nitrogen-fixing and celluloseproducing Gluconacetobacter kombuchae sp. nov., isolated from Kombucha tea. Int J Syst Evol Microbiol 57, 353-357.

Edgar, R. C. (2004). MUSCLE: multiple sequence alignment with high accuracy and high throughput. Nucleic Acids Res 32, 1792-1797.

Goodfellow, M. (1971). Numerical taxonomy of some nocardioform bacteria. J Gen Microbiol 69, 33-80. 
Gordon, R. E., Barnett, D. A., Handerhan, J. E. \& Pang, C. H.-N. (1974). Nocardia coeliaca, Nocardia autotrophica, and the Nocardin strain. Int J Syst Bacteriol 24, 54-63.

Gu, Q., Luo, H., Zheng, W., Liu, Z. \& Huang, Y. (2006). Pseudonocardia oroxyli sp. nov., a novel actinomycete isolated from surface-sterilized Oroxylum indicum root. Int J Syst Evol Microbiol 56, 2193-2197.

Hasegawa, T., Takizawa, M. \& Tanida, S. (1983). A rapid analysis for chemical grouping of aerobic actinomycetes. J Gen Appl Microbiol 29, 319-322.

Hong, K., Gao, A. H., Xie, Q. Y., Gao, H., Zhuang, L., Lin, H. P., Yu, H. P., Li, J., Yao, X. S. \& other authors (2009). Actinomycetes for marine drug discovery isolated from mangrove soils and plants in China. Mar Drugs 7, 24-44.

Kämpfer, P. \& Kroppenstedt, R. M. (1996). Numerical analysis of fatty acid patterns of coryneform bacteria and related taxa. Can $\mathrm{J}$ Microbiol 42, 989-1005.

Küster, E. (1972). Simple working key for the classification and identification of named taxa included in the International Streptomyces Project. Int J Syst Bacteriol 22, 139-148.

Labeda, D. P. (1992). DNA-DNA hybridization in the systematics of Streptomyces. Gene 115, 249-253.

Lechevalier, M. P. \& Lechevalier, H. (1970). Chemical composition as a criterion in the classification of aerobic actinomycetes. Int J Syst Bacteriol 20, 435-443.

Lechevalier, M. P., De Bievre, C. \& Lechevalier, H. A. (1977). Chemotaxonomy of aerobic actinomycetes: phospholipid composition. Biochem Syst Ecol 5, 249-260.

Locci, R. (1989). Streptomyces and related genera. In Bergey's Manual of Systematic Bacteriology, vol. 4, pp. 2451-2508. Edited by S. T. Williams, M. E. Sharpe \& J. G. Holt. Baltimore: Williams \& Wilkins.

Marmur, J. \& Doty, P. (1962). Determination of the base composition of deoxyribonucleic acid from its thermal denaturation temperature. J Mol Biol 5, 109-118.

Minnikin, D. E., O'Donnell, A. G., Goodfellow, M., Alderson, G., Athalye, M., Schaal, A. \& Parlett, J. H. (1984). An integrated procedure for the extraction of bacterial isoprenoid quinones and polar lipids. J Microbiol Methods 2, 233-241.

Nye, T. M. W., Liò, P. \& Gilks, W. R. (2006). A novel algorithm and web-based tool for comparing two alternative phylogenetic trees. Bioinformatics 22, 117-119.

Ostash, B., Kozarevska, I. \& Fedorenko, V. (2005). Generation of landomycin D-producing strain Streptomyces globisporus LD3. Folia Microbiol (Praha) 50, 19-23.
Posada, D. (2008). jModelTest: phylogenetic model averaging. Mol Biol Evol 25, 1253-1256.

Praveen, V., Tripathi, C. K. M., Bihari, V. \& Srivastava, S. C. (2008). Production of actinomycin-D by the mutant of a new isolate of Streptomyces sindenensis. Braz J Microbiol 39, 689-692.

Saha, M., Jaisankar, P., Das, S., Sarkar, K. K., Roy, S., Besra, S. E., Vedasiromani, J. R., Ghosh, D., Sana, B. \& Mukherjee, J. (2006). Production and purification of a bioactive substance inhibiting multiple drug resistant bacteria and human leukemia cells from a salttolerant marine Actinobacterium sp. isolated from the Bay of Bengal. Biotechnol Lett 28, 1083-1088.

Shirling, E. B. \& Gottlieb, D. (1966). Methods for characterization of Streptomyces species. Int J Syst Bacteriol 16, 313-340.

Shirling, E. B. \& Gottlieb, D. (1968a). Cooperative description of type cultures of Streptomyces. II. Species descriptions from first study. Int $J$ Syst Bacteriol 18, 69-189.

Shirling, E. B. \& Gottlieb, D. (1968b). Cooperative description of type cultures of Streptomyces. III. Additional species descriptions from first and second studies. Int J Syst Bacteriol 18, 279-392.

Shirling, E. B. \& Gottlieb, D. (1969). Cooperative description of type cultures of Streptomyces. IV. Species descriptions from the second, third and fourth studies. Int J Syst Bacteriol 19, 391-512.

Shirling, E. B. \& Gottlieb, D. (1972). Cooperative description of type strains of Streptomyces. V. Additional description. Int J Syst Bacteriol 22, 265-394.

Staneck, J. L. \& Roberts, G. D. (1974). Simplified approach to identification of aerobic actinomycetes by thin-layer chromatography. Appl Microbiol 28, 226-231.

Stöver, B. C. \& Müller, K. F. (2010). TreeGraph 2: combining and visualizing evidence from different phylogenetic analyses. BMC Bioinf $11,7$.

Swofford, D. L. (2002). PAUP ${ }^{*}$ Phylogenetic analysis using parsimony ( ${ }^{\star}$ and other methods). Sunderland, MA: Sinauer Associates.

Tresner, H. D., Hayes, J. A. \& Backus, E. J. (1968). Differential tolerance of streptomycetes to sodium chloride as a taxonomic aid. Appl Microbiol 16, 1134-1136.

Williams, S. T., Goodfellow, M., Alderson, G., Wellington, E. M. H., Sneath, P. H. A. \& Sackin, M. J. (1983). Numerical classification of Streptomyces and related genera. J Gen Microbiol 129, 1743-1813.

Zaheer, A., Zaheer, S. \& Montgomery, R. (1985). Proteolytic activity of largomycin. Biochim Biophys Acta 841, 261-266.

Zhou, Z. H., Liu, Z. H., Qian, Y. D., Kim, S. B. \& Goodfellow, M. (1998). Saccharopolyspora spinosporotrichia sp. nov., a novel actinomycete from soil. Int J Syst Bacteriol 48, 53-58. 